\title{
Differential expression of mycobacterial proteins following phagocytosis by macrophages
}

\author{
Irene M. Monahan, ${ }^{1}$ Joanna Betts, ${ }^{2}$ Dilip K. Banerjee ${ }^{1}$ \\ and Philip D. Butcher ${ }^{1}$
}

Author for correspondence: Philip D. Butcher. Tel: +44 208725 5721. Fax: +44 2086720234.

e-mail: butcherp@sghms.ac.uk

1 Department of Medical Microbiology, St George's Hospital Medical School, Cranmer Terrace, London SW17 ORE, UK

2 Respiratory Systems, Glaxo Wellcome Research and Development, Medicines Research Centre, Gunnels Wood Road, Stevenage SG1 2NY, UK

\begin{abstract}
Mycobacterium tuberculosis resides within the macrophages of the host, but the molecular and cellular mechanisms of survival are poorly understood. Recent evidence suggests that the attenuated vaccine strain Mycobacterium bovis BCG is both a deletion and regulatory mutant, yet retains both its immunoprotective and intra-macrophage survival potential. In an attempt to define $M$. bovis BCG genes expressed during interaction with macrophages, the patterns of protein synthesis were examined by both one- and twodimensional gel electrophoresis of BCG while inside the human leukaemic macrophage cell line THP-1. This study demonstrated that BCG expresses proteins while resident inside macrophages that are not expressed during in vitro growth in culture media or under conditions of heat shock. Western blotting analysis revealed that some of the differentially expressed proteins are specifically recognized by human $M$. tuberculosis-infected sera. Proteome analysis by two-dimensional electrophoresis and MS identified six abundant proteins that showed increased expression inside macrophages: $16 \mathrm{kDa}$ $\alpha$-crystallin (HspX), GroEL-1 and GroEL-2, a $31 \cdot 7 \mathrm{kDa}$ hypothetical protein (Rv2623), InhA and elongation factor Tu (Tuf). Identification of proteins by such a strategy will help elucidate the molecular basis of the attenuation and the vaccine potential of BCG, and may provide antigens that distinguish infection with $M$. tuberculosis from vaccination with BCG.
\end{abstract}

Keywords: mycobacteria, gene expression, macrophages, proteomics, tuberculosis

\section{INTRODUCTION}

Mycobacterium tuberculosis is a facultative intracellular pathogen, which can reside within the macrophages of the host. The major immunopathology associated with tuberculosis (TB) results from interactions between the live tubercle bacillus and the host's immune response. This suggests, therefore, that M. tuberculosis may respond to the intracellular milieu of the macrophage with the induction of environmentally regulated genes required for survival and growth of the bacteria. However, the mechanisms underlying this Mycobac-

Abbreviations: 1D, one-dimensional; 2D, two-dimensional; EF-Tu elongation factor Tu; MALDI, matrix-assisted laser desorption ionization; nanoES, nanoelectrospray; PMA, phorbol 12-myristate 13-acetate; TB, tuberculosis. terium-macrophage interaction are poorly understood at both the molecular and cellular levels.

Other intracellular bacterial pathogens undergo a series of genetic regulatory responses following uptake by and contact with the host cell that facilitates their intracellular survival and growth. The expression of such virulence determinants is co-ordinately regulated by two-component sensor-regulator systems which respond to specific stimuli such as iron depletion, $\mathrm{pH}$, oxidative stress and heat, all of which may be associated with different stages of interaction with the host (Mekalanos, 1992). Accumulating evidence suggests that M. tuberculosis undergoes co-ordinated gene expression responses to signals associated with infection, and a series of homologues of virulence gene response regulators have been identified (Cole et al., 1998; Gupta \& Tyagi, 1993; Wren et al., 1992). Indeed, the two- 
component system $m \operatorname{tr} A-m \operatorname{tr} B$ in $M$. tuberculosis has been shown to be activated within macrophages (Via et al., 1996). In addition to this, M. tuberculosis has been shown to possess $r p o V$, ivg and $k a t G$ genes, which are involved in the growth and survival of virulent strains in animal models (Collins et al., 1995; Pascopella et al., 1994; Wilson et al., 1995). It also has homologues of the Yersinia invasin and Listeria internalin genes, mce (Arruda et al., 1993), as well as genes which are differentially expressed in the virulent phenotype (Kinger \& Tyagi, 1993). Furthermore, a gene (mig) encoding a secreted protein has been identified as being specifically induced by Mycobacterium avium inside macrophages (Plum \& Clark-Curtiss, 1994; Plum et al., 1997), and both virulent and avirulent strains of $M$. tuberculosis and M. avium have been shown to express a series of differentially expressed proteins in response to infection of either murine or human macrophages (Alavi \& Affronti, 1994; Lee \& Horwitz, 1995; SturgillKoszycki et al., 1997).

To provide further evidence for gene regulation in response to signals associated with infection, and to identify immunoreactive intracellular antigens which may be important targets of the immune response in TB infection, we have defined the patterns of gene expression of Mycobacterium bovis BCG while inside the human leukaemic macrophage cell line THP-1. BCG is an attenuated vaccine strain, yet it retains its ability to survive within the macrophage. We have developed an in vitro macrophage infection model that permits the recovery of intracellular bacilli free from contaminating host cell proteins. This facilitates the subsequent detection by electrophoresis, the immunological characterization by Western blotting with TB-infected human sera and the identification by proteomics of intracellularly expressed bacterial proteins. In this way, it may be possible to monitor the adaptive gene expression responses of BCG inside macrophages, which may ultimately shed some light on the efficacy of BCG as a vaccine.

\section{METHODS}

Mycobacteria and culture. M. bovis BCG Pasteur strain was cultured in Dubos broth supplemented with $10 \%$ (v/v) Dubos medium albumin (Difco) at $37^{\circ} \mathrm{C}$ and harvested at midexponential phase after $8-10 \mathrm{~d}$ at a density of $2-5 \times 10^{7}$ bacilli $\mathrm{ml}^{-1}$. These cultures were used for both in vitro radiolabelling and macrophage infection. All manipulations of mycobacteria prior to radiolabelling were carried out at $37^{\circ} \mathrm{C}$ so as to avoid inducing a stress response due to temperature fluctuations.

Macrophage culture and infection with $\boldsymbol{M}$. bovis BCG. The human leukaemic macrophage cell line THP-1 was routinely maintained as suspended cells in RPMI 1640 media (ICN Biomedicals) supplemented with $10 \%(\mathrm{v} / \mathrm{v})$ heat-inactivated fetal calf serum (Life Technologies), $2 \mathrm{mM}$ glutamine, penicillin (100 i.u. $\mathrm{ml}^{-1}$ ) (Life Technologies) and streptomycin $\left(100 \mu \mathrm{g} \mathrm{ml}^{-1}\right)$ (Life Technologies) at $37^{\circ} \mathrm{C}$ in a $5 \% \mathrm{CO}_{2}$ humidified incubator. Cells were grown to a density of $2-5 \times 10^{6}$ cells $\mathrm{ml}^{-1}$ in $25 \mathrm{~cm}^{2}$ flat-bottom tissue culture flasks and passaged every $4 \mathrm{~d}$. Prior to infection with mycobacteria, the THP-1 cells were passaged at least three times in supplemented antibiotic-free RPMI 1640 growth medium before expansion of the cells into $175 \mathrm{~cm}^{2}$ flat-bottom tissue culture flasks containing $30 \mathrm{ml}$ RPMI 1640 growth medium. The cells, which were grown to a density of $2-5 \times 10^{6} \mathrm{ml}^{-1}$, were stimulated with $20 \mathrm{nM}\left(12 \mathrm{ng} \mathrm{ml}^{-1}\right)$ phorbol 12-myristate 13 -acetate (PMA; Sigma) for $24 \mathrm{~h}$ so as to allow the cells to adhere. Non-adherent cells were removed by washing twice in warm RPMI 1640 and the resulting monolayers (approx. $3-5 \times 10^{7}$ cells per flask) were covered with $30 \mathrm{ml}$ supplemented RPMI 1640 growth medium. Mid-exponential phase M. bovis BCG $\left(5 \times 10^{8}\right.$ bacilli) were recovered from Dubos broth by centrifugation at $5000 \mathrm{~g}$ for $10 \mathrm{~min}$, resuspended in $1 \mathrm{ml}$ supplemented RPMI 1640 growth media and sonicated for $15 \mathrm{~s}(5 \times 3 \mathrm{~s}$ bursts at $70 \%$ amplitude $)$ so as to disperse any clumps. The mycobacterial sonicate was added to the adhered macrophage monolayer at an infection ratio of 10 bacilli per macrophage and left to phagocytose for $24 \mathrm{~h}$ at $37^{\circ} \mathrm{C}$ in a humidified $5 \% \mathrm{CO}_{2}$ incubator. Extracellular mycobacteria were removed by decanting the supernatant and extensively washing the adhered cells twice in warm RPMI 1640. To monitor protein synthesis patterns at varying time intervals after phagocytosis, a $12 \mathrm{~h}$ period of phagocytosis was allowed, after which time extracellular mycobacteria were removed by decanting the growth medium, washing twice in warm RPMI 1640 and replenishing the infected macrophages with $30 \mathrm{ml}$ supplemented RPMI 1640. This experiment was also performed using a sonicate of heat-killed $M$. bovis BCG. Macrophage viability, which never fell below $90 \%$ throughout these experiments, was assessed by Trypan blue exclusion. Intracellular mycobacterial growth was determined at 12, 24, 48 and $72 \mathrm{~h}$ after infection via Ziehl-Neelsen acid-fast staining and viable counts.

Radiolabelling and SDS-PAGE analysis of intracellular $\boldsymbol{M}$. bovis BCG proteins. Radiolabelling of intracellular mycobacteria was carried out at $12,24,48$ and $72 \mathrm{~h}$ after phagocytosis. RPMI 1640 media without methionine and cysteine $(25 \mathrm{ml})$ was added to each flask and the intracellular BCG were radiolabelled for $2 \mathrm{~h}$ at $37^{\circ} \mathrm{C}$ in $5 \% \mathrm{CO}_{2}$ by the addition of $9 \cdot 25 \mathrm{MBq}\left[{ }^{35} \mathrm{~S}\right]$ methionine (Tran ${ }^{35} \mathrm{~S}$-label; ICN Biomedicals) (>37 TBq mmol ${ }^{-1}$; containing $70 \%$ L$\left[{ }^{35} \mathrm{~S}\right]$ methionine and $15 \% \mathrm{~L}-\left[{ }^{35} \mathrm{~S}\right]$ cysteine) to each infected flask of macrophages. Uninfected, PMA-stimulated THP-1 cells were also radiolabelled in the same manner and used as a control. The cells were then chased with $100 \mathrm{mM}$ cold L-methionine for $10 \mathrm{~min}$, the supernatant was poured off and the cells were washed twice in warm PBS $(150 \mathrm{mM}$ sodium chloride, $10 \mathrm{mM}$ sodium phosphate, $\mathrm{pH} 7 \cdot 0$ ) so as to remove any excess unincorporated isotope. One hundred millilitres of SDS $(0 \cdot 25 \%, \mathrm{w} / \mathrm{v})$ was added to each flask and left for $5 \mathrm{~min}$ at $37^{\circ} \mathrm{C}$ to lyse the cells. The lysed cell suspension was pipetted rapidly with a long nose plastic pastette and passed through a $23 \mathrm{G}$ needle so as to reduce the viscosity. It was then transferred to $30 \mathrm{ml}$ plastic universals and centrifuged at $5000 \mathrm{~g}$ for $20 \mathrm{~min}$. Pelleted mycobacteria were pooled and washed a further two times in PBS containing $1 \%(\mathrm{v} / \mathrm{v})$ Tween 80 so as to remove any contaminating macrophage proteins. The washed mycobacterial pellet was then resuspended in $1 \mathrm{ml} \mathrm{PBS} / 1 \%$ Tween 80 , transferred to $1.5 \mathrm{ml}$ screwcapped microcentrifuge tubes and pelleted at $11500 \mathrm{~g}$ in a microcentrifuge for $5 \mathrm{~min}$. The supernatant was removed and an equal volume of glass beads (acid-washed, $100 \mu \mathrm{m}$ diameter; Sigma) were added to the bacterial pellet along with $15 \mu \mathrm{l}$ PBS, which was then vortexed for $5 \mathrm{~min}$ at room temperature so as to mechanically lyse the bacilli. The mycobacterial proteins were finally solubilized in $15 \mu \mathrm{l}$ (equal 
volume) of $2 \times$ SDS sample buffer (Laemmli, 1970) and boiled for $10 \mathrm{~min}$. Equal loading of samples was determined by running a small aliquot on a preliminary gel, silver staining and adjusting the total protein content accordingly. Solubilized mycobacterial proteins were analysed by SDS-PAGE (Laemmli, 1970). Following silver staining (Morrissey, 1981), gels were impregnated with fluorographic enhancer (Amplify; Amersham) for $30 \mathrm{~min}$, dried and exposed to pre-flashed Hyperfilm-MP X-ray film (Amersham) at $-70^{\circ} \mathrm{C}$ for 23 weeks.

Two-dimensional (2D) gel electrophoresis. 2D gel analysis of total mycobacterial proteins was carried out using the Investigator 2D Electrophoresis System (Genomic Solutions) based on the method of O'Farrell (1975). Briefly, samples were boiled in lysis buffer $(0.3 \%$ SDS, $200 \mathrm{mM}$ DTT, $50 \mathrm{mM}$ Tris $\mathrm{pH} 8.0)$ and solubilized in $9.9 \mathrm{M}$ urea/ampholyte sample buffer prior to electrophoretic analysis. Protein concentrations of each solubilized sample (diluted at least tenfold in water prior to the addition of urea/ampholytes) were assessed using a standard protein assay (Bio-Rad) based on the Bradford (1976) method so as to ensure equal loading of each preparation. Proteins were focused in the first dimension in polyacrylamide gels within a $\mathrm{pH}$ range of 3-10, and resolved in the second dimension on $10 \%$ acrylamide slab gels. Total protein profiles were analysed by silver staining (Morrissey, 1981).

Sample preparation for MS. Protein spots of interest were excised from the gel, reduced, carboxyamidated and digested in situ with trypsin as described by Shevchenko et al. (1996) and Wilm et al. (1996). After digestion overnight at $37^{\circ} \mathrm{C}$, samples were centrifuged and an aliquot of the supernatant taken for analysis by matrix-assisted laser desorption ionization (MALDI) MS. Prior to nanoelectrospray (nanoES) analysis, peptides were extracted from the gel pieces as described by Jensen et al. (1999).

MALDI MS. This was performed on a VG TofSpec SE time-offlight (TOF) mass spectrometer equipped with a delayed extraction ion source (Micromass). Samples were prepared largely as described by Jensen et al. (1996). A saturated solution of $\alpha$-cyano-4-hydroxycinnamic acid in acetone was mixed in a $4: 1(\mathrm{v} / \mathrm{v})$ ratio with a solution containing $10 \mathrm{~g}$ nitrocellulose $\mathrm{l}^{-1}$ (Trans-Blot transfer medium, $0 \cdot 45 \mu \mathrm{m}$; Bio$\mathrm{Rad})$ in acetone/2-propanol $(1: 1, \mathrm{v} / \mathrm{v})$. This was deposited on the stainless steel target in $0.6 \mu$ l aliquots, leaving a matrix/nitrocellulose surface by fast evaporation of the solvent. Aliquots of $0.5 \mu \mathrm{l}$ volume were taken from the tryptic digest mixture and loaded into a $0.5 \mu \mathrm{l}$ droplet of $5 \%(\mathrm{v} / \mathrm{v})$ formic acid previously applied to the matrix. Samples were air-dried at room temperature and washed with $1 \mu \mathrm{l} 5 \%$ formic acid prior to insertion into the instrument. Spectra were internally calibrated using the matrix ion at $\mathrm{m} / z 1060 \cdot 10$ and trypsin autolysis peaks at $m / z 2163.06$ and $m / z 2289 \cdot 15$. Monoisotopic masses were assigned and proteins identified by peptide mass fingerprinting using Pepsea software (Protana) and a mass accuracy of $0 \cdot 1 \mathrm{Da}$.

NanoES MS. Any proteins not identified by MALDI MS were subsequently analysed by tandem nanoES MS. Dried digest mixtures were desalted prior to analysis. Pulled glass capillaries were packed with approximately $5 \mu$ l POROS R2 sorbent (PerSeptive Biosystems). Peptides were dissolved in $0.5 \%$ formic acid, loaded on to the sorbent and washed with $5 \mu \mathrm{l} 0.5 \%$ formic acid. Samples were eluted with approximately $2 \mu \mathrm{l} 1 \%(\mathrm{v} / \mathrm{v})$ formic acid, $50 \%(\mathrm{v} / \mathrm{v})$ methanol and a $1 \mu \mathrm{l}$ aliquot inserted into the spraying needle. Needles for electrospraying were made with a micropipette puller (Sutter Instrument) from borosilicate glass capillaries (Clark Electromedical Instruments) as described by Wilm \& Mann (1996) and were gold-coated in a vapour desorption instrument. Electrospray mass spectra were acquired on an API III triple quadrupole machine (Perkin-Elmer Sciex) equipped with a nanoES ion source developed by Wilm \& Mann $(1994,1996)$. Proteins were identified by the sequence tag approach (Mann \& Wilm, 1994) using Pepsea software (Protana).

Radiolabelling of $M$. bovis BCG with $\left[{ }^{35} \mathrm{~S}\right]$ methionine in vitro. Mid-exponential-phase BCG $\left(5 \times 10^{8}\right.$ bacilli) were radiolabelled for $2 \mathrm{~h}$ with $4.625 \mathrm{MBq}\left[{ }^{35} \mathrm{~S}\right]$ methionine in Dubos broth at $37^{\circ} \mathrm{C}$ and at $45^{\circ} \mathrm{C}$ heat shock, and during a 12 and a $24 \mathrm{~h}$ incubation period in RPMI 1640 growth medium. Extracellular BCG removed after the 12 and 24 phagocytosis periods as described above were collected by centrifugation at $5000 \mathrm{~g}$, washed twice in PBS/1\% Tween 80 and resuspended in methionine- and cysteine-free RPMI 1640. The bacteria were radiolabelled with $4.625 \mathrm{MBq}\left[{ }^{35} \mathrm{~S}\right]$ methionine for $2 \mathrm{~h}$ at $37{ }^{\circ} \mathrm{C}$ in a humidified $5 \% \mathrm{CO}_{2}$ incubator. All of the reactions were terminated by chasing with $100 \mathrm{mM}$ cold L-methionine for $10 \mathrm{~min}$, followed by chilling on ice. The bacteria were washed twice in PBS/1\% Tween 80 and solubilized for SDSPAGE analysis as described above.

Analysis of immunoreactive intracellular antigens. Western blot analysis of total proteins separated by SDS-PAGE was performed by electrotransfer to Hybond C (Amersham) nitrocellulose using a Tris/glycine transfer buffer $[20 \mathrm{mM}$ Tris/ $\mathrm{HCl} \mathrm{pH} 8 \cdot 3,136 \mathrm{mM}$ glycine, $25 \%$ (v/v) methanol]. Following blocking with $5 \%(\mathrm{w} / \mathrm{v})$ non-fat milk in Tween/Tris-buffered saline [TTBS; $20 \mathrm{mM}$ Tris/ $\mathrm{HCl} \mathrm{pH} \mathrm{7•4,}$ $0.9 \%(\mathrm{w} / \mathrm{v}) \mathrm{NaCl}, 0.1 \%(\mathrm{v} / \mathrm{v})$ Tween 20], proteins were immunologically detected using a 1:1000 dilution in TTBS of polyclonal $\mathrm{IgG}$ from rabbit immunized with a sonicate of M. bovis BCG (Copenhagen) containing soluble and insoluble antigens (Dakopatts). After washing, immunoreactive proteins were visualized with biotin-conjugated goat anti-rabbit IgG at a dilution of $1: 1000$ in TTBS via a colorimetric assay with streptavidin-alkaline phosphatase conjugate (Amersham; diluted 1:2000 in TTBS), nitro blue tetrazolium (NBT; Life Technologies) and 5-bromo-4-chloro-3-indoyl phosphate (BCIP; Life Technologies) using standard protocols.

Analysis of immunoreactive proteins using human sera (TBinfected, BCG-vaccinated and non-vaccinated, uninfected) and an anti-65 kDa mAb (kindly provided by Dr Douglas Lowrie, National Institute of Medical Research, Mill Hill, London) was also performed. Sera from human TB patients (acute infections with M. tuberculosis) were obtained from Hong Kong and kindly provided by Professor D. A Mitchison, St George's Hospital Medical School (SGHMS), London. Both BCG-vaccinated and non-vaccinated, uninfected child sera (ranging from 6 months to 2 years in age) were kindly provided by the Virology Public Health Laboratory, SGHMS, London. Following blocking and washing, the nitrocellulose membranes were incubated with a 1:100 dilution of each sera type and a 1:500 dilution of the $\mathrm{mAb}$ in TTBS containing $10 \%(\mathrm{v} / \mathrm{v})$ goat sera (Tissue Culture Services). After washing, the membranes were then incubated with a 1:1000 dilution (in TTBS containing 10\% goat sera) of anti-human IgG biotinylated whole antibody from goat (Amersham). The remaining procedure then continued as described above. 


\section{RESULTS}

\section{Intracellular M. bovis BCG profiles}

The intracellular replication of $M$. bovis BCG within THP-1 cells, as assessed by Ziehl-Neelsen staining, showed a linear increase from $2 \cdot 8$ acid-fast bacilli (AFB) per macrophage at $12 \mathrm{~h}$ to $14 \cdot 2 \mathrm{AFB}$ per macrophage at $72 \mathrm{~h}$. Similarly, the total viable counts increased from $1.7 \times 10^{5}$ c.f.u. $\mathrm{ml}^{-1}$ at $12 \mathrm{~h}$ to $5 \cdot 4 \times 10^{5}$ c.f.u. $\mathrm{ml}^{-1}$ at $72 \mathrm{~h}$. These observations demonstrate that this in vitro macrophage infection model was able to support the growth of intracellular $M$. bovis BCG without any observed killing and therefore provided a system in which to examine the gene expression profiles of mycobacteria while resident within macrophages. To examine the intracellular modulation of mycobacterial protein synthesis over time, $M$. bovis BCG resident within THP-1 cells were radiolabelled with $\left[{ }^{35} \mathrm{~S}\right]$ methionine and the proteins separated by one-dimensional
(1D) gel electrophoresis. Cycloheximide was not used to inhibit host cell protein synthesis. Intracellular protein profiles at $12,24,48$ and $72 \mathrm{~h}$ after phagocytosis were analysed at the de novo synthesis level by fluorography and compared to in-vitro-grown broth cultures. A representative example of the protein profile obtained is presented in Fig. 1.

Comparison of the intracellular BCG protein patterns (lanes 4-7) with in-vitro-grown BCG at $37{ }^{\circ} \mathrm{C}$ (lane 1) and in RPMI media (lane 3), revealed a number of discernible protein bands that showed both qualitative and quantitative differential expression (see Discussion). Intracellular gene expression also varied with time (12-72 h; lanes 4-7) with the majority of modulation occurring within the first $24 \mathrm{~h}$ after phagocytosis. These differentially expressed protein bands, some of which appear to be specifically induced within the macrophage (see legend of Fig. 1), ranged in size from 110 to $14 \mathrm{kDa}$ and are indicated by arrows in Fig. 1. The analysis of

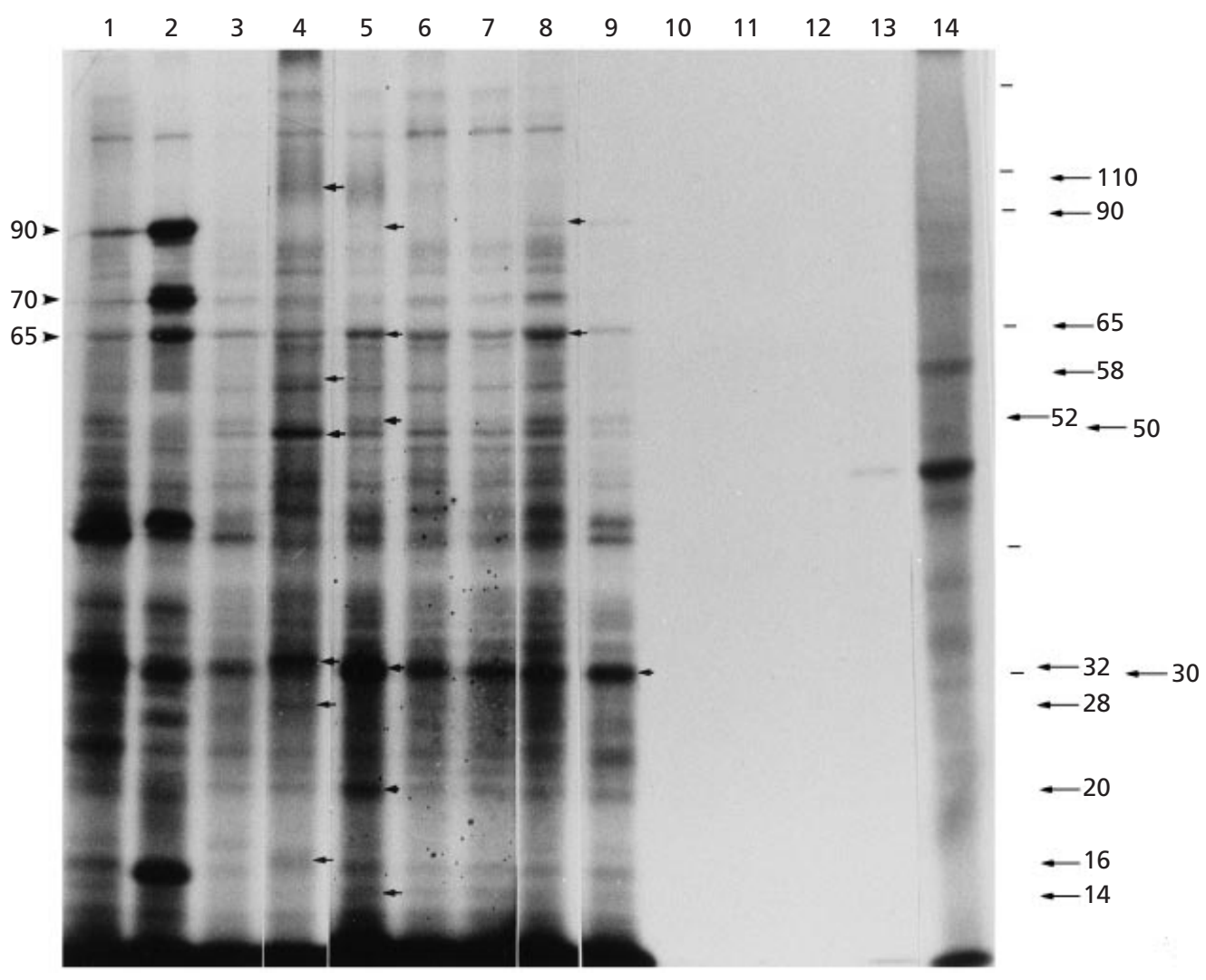

Fig. 1. Time course analysis by $10 \%$ SDS-PAGE of $M$. bovis BCG proteins synthesized within THP-1 cells and visualized by fluorography. After a $12 \mathrm{~h}$ phagocytosis period, intracellular BCG were radiolabelled for $2 \mathrm{~h}$ and recovered at intervals of 12 (lane 4), 24 (lane 5), 48 (lane 6) and 72 (lane 7) h after phagocytosis. In-vitro-grown BCG before (lane 1) and after (lane 2) heat shock, and after incubation in RPMI 1640 for $24 \mathrm{~h}$ (lane 3) were included as controls. Similarly, heat-killed BCG which were phagocytosed and recovered from THP-1 cells at 12 (lane 10) and 24 (lane 11) h were used to control for contaminating host cell proteins. Lanes 8 and 9 represent extracellular BCG which had been in direct contact with THP-1 cells for 12 and $24 \mathrm{~h}$, respectively. Macrophage cell lysate (lanes 12 and 13) and total macrophage proteins (lane 14) were also included. Arrowheads indicate the major heat-shock proteins induced and their apparent molecular masses in kDa. Arrows indicate proteins differentially expressed during infection. Proteins of molecular mass 110, 28 and $16 \mathrm{kDa}$ appear to be specifically induced within the macrophage. Pointers indicate the positions of the molecular mass markers used (from top to bottom, 205, 116, 97, 66, 45 and $29 \mathrm{kDa}$ ). 
individual proteins was difficult to interpret due to the overcrowding of bands and the inability to separate out individual proteins of similar molecular mass that may contribute to a single band seen on 1D gels. 2D gel analysis allows individual proteins to be resolved (see below). However, the expression of proteins in the molecular mass range of about $65 \mathrm{kDa}$ was readily seen to increase at $24 \mathrm{~h}$ following phagocytosis (lane 5 ) and was sustained through to $48 \mathrm{~h}$ (lane 6) after which time synthesis was reduced. This was confirmed by an immunoblot analysis using the anti-65 $\mathrm{kDa} \mathrm{mAb}$ (Fig. 2a). This showed that the level of expression of the $65 \mathrm{kDa}$ antigen increased after $12 \mathrm{~h}$ (lane 2) through to $48 \mathrm{~h}$ post-phagocytosis (lane 4) compared to the in vitro control (lane 1). The observed increase in the level of expression was not due to unequal protein loading, as demonstrated by the corresponding silver-stained total protein profile (Fig. $2 \mathrm{~b}$ ). The $65 \mathrm{kDa}$ band was also clearly up-regulated in response to heat shock, along with the other major heat-shock proteins Hsp70 and Hsp90 (Fig. 1, lane 2). We used this heat inducibility of protein synthesis as a measure of the integrity of the gene expression responses to environmental stress for each BCG batch used in the macrophage infection experiments. The heat shock induced de novo synthesis and the total protein profiles were consistent with our previous studies (Patel et al., 1991).

To exclude the possibility that changes in protein profile of the intracellular BCG fractions compared to in vitro cultures might have been due either (i) to carryover of macrophage proteins, or (ii) to changes associated with different media or subsequent handling conditions, a range of control experiments were performed and the results are included in Fig. 1. The protein profile of radiolabelled BCG incubated in RPMI 1640 (lane 3) showed minor differences (e.g. $90 \mathrm{kDa}$ band) to the invitro-grown $37^{\circ} \mathrm{C}$ control (lane 1), as well as differences to the intracellular fractions. These profiles indicated that the protein differences observed in intracellular mycobacteria were not a result of medium changes. Secondly, in order to exclude the possibility of macrophage proteins contaminating the intracellular mycobacterial fraction, heat-killed BCG cells were phagocytosed, radiolabelled and recovered at 12 and $24 \mathrm{~h}$ after infection (lanes 10 and 11, respectively). No radiolabelled macrophage protein was observed. Similarly, direct loading of an excess of radiolabelled macrophage lysate supernatant after the removal of intracellular BCG by centrifugation, showed only the presence of very faint macrophage-derived bands (lanes 12 and 13). These results clearly indicate that macrophage proteins were not carried over into the bacterial pellets and were diluted to such an extent in the lysis and washing steps that their contribution to the intracellular mycobacterial protein profile on the gels was negligible. The intracellular profiles (lanes 4-7) also differed significantly from that of the macrophage protein control (lane 14), as expected. In an attempt to see if proteins were differentially expressed by mycobacteria that had been in direct contact with macrophages but not phago- cytosed, extracellular BCG (i.e. bacilli that remained outside the macrophages and could be washed off) were radiolabelled and recovered at 12 and $24 \mathrm{~h}$ post-contact with THP-1 cells (lanes 8 and 9, respectively). The extracellular patterns showed some evidence of protein modulation (as indicated by arrows), which was similar to that of the intracellular protein profiles after recovery at $12-72 \mathrm{~h}$.

As a further control to exclude macrophage protein carryover, total protein extracts from $M$. bovis BCG recovered after $24 \mathrm{~h}$ from THP-1 cells, from in-vitrogrown BCG before and after heat shock and from uninfected THP-1 cells were analysed by Western blotting using a specific anti-BCG polyclonal rabbit $\operatorname{IgG}$ antibody. The results are presented in Fig. 3. Mycobacterial proteins, both in vitro (lanes 2 and 3 ) and after recovery from macrophages (lane 1), reacted strongly, whereas the molecular mass markers (lane 4) and macrophage proteins (lane 5) demonstrated only very weak cross-reactivity. This experiment indicated that the proteins from the intracellular BCG fraction were clearly mycobacterial in origin and that carryover macrophage proteins could not therefore account for the differentially expressed intracellular profiles observed. In addition to this, differences in the expression of certain immunogenic proteins were clearly observed between intracellular and in-vitro-grown BCG, as indicated by arrows.

\section{D gel electrophoresis of intracellular mycobacterial proteins and proteomics}

To further characterize the differentially expressed proteins observed following 1D gel electrophoresis, intracellular $M$. bovis BCG were recovered from THP-1 cells $24 \mathrm{~h}$ after phagocytosis, a time period that appeared to produce maximum changes in protein expression (see Fig. 1), and the proteins analysed by 2D gel electrophoresis. Intracellular BCG protein profiles were compared to in-vitro-grown cultures of BCG. The results presented show a representative example of invitro-grown (Fig. 4a) and intracellularly recovered (Fig. 4b) BCG. Low-molecular-mass proteins were resolved using $12.5 \%$ SDS-PAGE second dimension gels and a representative section is shown in Fig. 4(c). At least 20 different BCG proteins were seen to be differentially expressed in response to infection of THP-1 cells (indicated by both squares and circles). The vast majority of proteins focused in the $\mathrm{pH}$ range $4 \cdot 0-6 \cdot 0$. Several abundant proteins were observed to be only expressed inside macrophages (squares) and ranged in molecular mass from approximately 110 to $38 \mathrm{kDa}$. In addition, many mycobacterial proteins in the molecular mass range $65-14 \mathrm{kDa}$ were up-regulated $24 \mathrm{~h}$ postphagocytosis compared to the in-vitro-grown control (indicated by circles). We have been able to identify six of these proteins by MALDI and nanoES MS. These were the GroEL homologues GroEL-1 (spot 2) and 

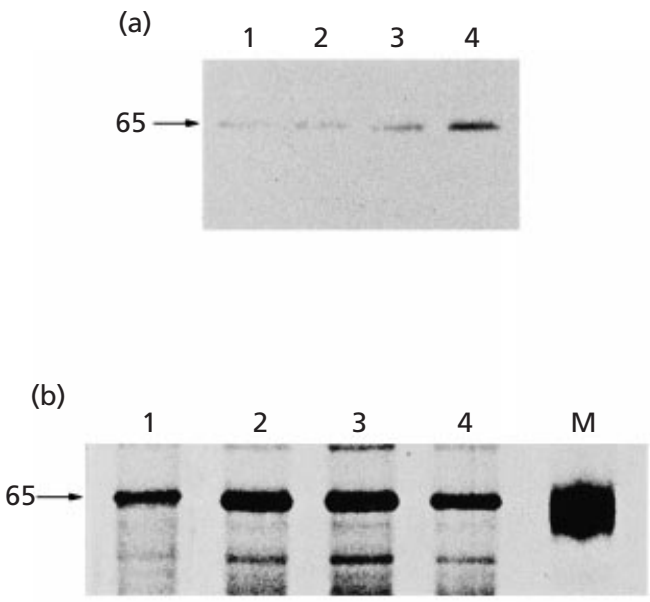

Fig. 2. Immunoblot analysis monitoring the expression of the $65 \mathrm{kDa} M$. bovis BCG antigen during phagocytosis by THP-1 cells. (a) BCG grown in vitro (lane 1) and intracellular BCG recovered from THP-1 cells at intervals of 12 (lane 2), 24 (lane 3) and 48 (lane 4) $\mathrm{h}$ after phagocytosis were separated by $10 \%$ SDS-PAGE, blotted and probed with the mycobacterial $65 \mathrm{kDa}$ mAb. (b) Corresponding silver-stained total protein profile of the $M$. bovis BCG samples used in the immunoblot. Lane $M$, $66 \mathrm{kDa}$ molecular mass marker.

GroEL-2 (spot 1), InhA (spot 5), the $16 \mathrm{kDa} \alpha$-crystallin (HspX, spot 6; see Fig. 5c), elongation factor Tu [EF-Tu (Tuf), spot 3] and a hypothetical $31.7 \mathrm{kDa}$ protein (spot 4). Details of the predicted pI, molecular masses and peptides matched are presented in Table 1.

Criteria used to determine a positive identification by MALDI MS were at least three matching peptides with $0 \cdot 1 \mathrm{Da}$ mass accuracy. The $\mathrm{pI}$ and molecular mass of the identified protein were also checked against the spot position on the gel. For nanoES MS, sequence data from at least two matching peptides is normally required for an unambiguous identification. However, this was not achieved in the case of InhA (spot 5) where only one peptide was matched due to the low amount of sample present. When the peptide sequence tag obtained for this peptide was searched against the whole of the nonredundant protein database with an open mass accuracy of $3 \mathrm{Da}, 11$ matches were obtained. The top five matches were to the same peptide (SNLVAAGPIR) from enoylacyl carrier proteins from various mycobacterial species including M. tuberculosis, M. avium and Mycobacterium smegmatis. The predicted and observed fragment masses for this peptide matched well. The other peptides listed were poor matches and none related to either M. bovis, M. tuberculosis or the common contaminants trypsin and keratin. Searching just a M. tuberculosis database gave no hits other than InhA. All other peptides analysed from this spot were found to relate either to trypsin or keratin. These findings, together with the fact that the spot position on the gel is consistent with the identification, gave us confidence in the unambiguous identification of spot 5 as InhA. More than 10 other

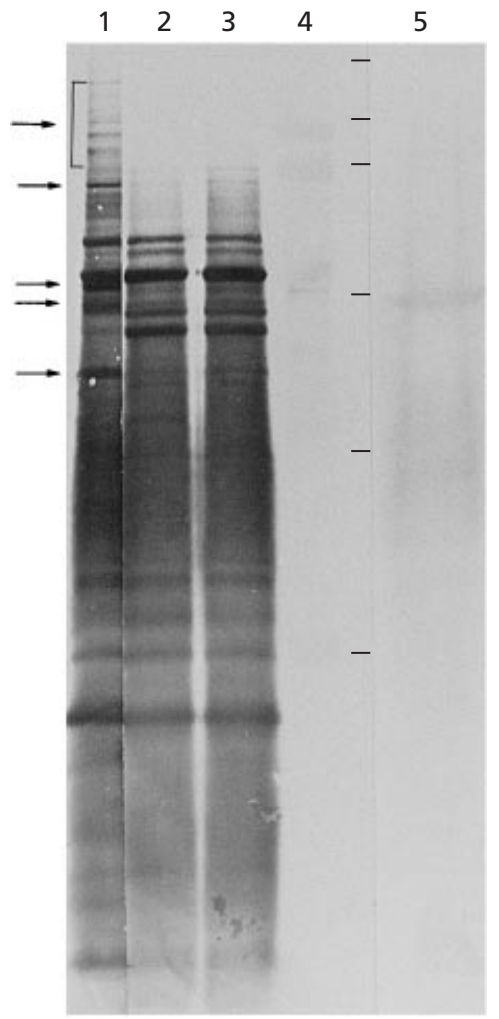

Fig. 3. Immunoblot analysis of mycobacterial proteins after reaction with rabbit anti- $M$. bovis BCG immunoglobulin. Intracellular BCG recovered after $24 \mathrm{~h}$ phagocytosis (lane 1), BCG before (lane 2) and after (lane 3) heat shock at $45^{\circ} \mathrm{C}$ and total THP-1 proteins (lane 5) were analysed by immunoelectrophoretic blotting with a commercial polyclonal IgG from rabbit immunized with a sonicate of $M$. bovis BCG. Molecular mass markers (lane 4) are as described in the legend to Fig. 1. Arrows indicate differentially expressed immunogenic intracellular antigens.

differentially expressed proteins failed to provide peptide mass data for subsequent identification, due to suboptimal amounts for analysis by MS.

\section{Immunological recognition of intracellularly expressed $\boldsymbol{M}$. bovis BCG antigens}

To investigate whether intracellularly expressed antigens are recognized by the human humoral immune system and to explore any significance of selective antigen recognition in terms of vaccination status or infection with $M$. tuberculosis, a Western blot was performed with human sera from selected patient groups: non-vaccinated, uninfected children $(n=3)$, a BCG-vaccinated individual $(n=1)$ and active cases of M. tuberculosis infection $(n=5)$. The immunoblot results of selected sera from these three populations comparing intracellular M. bovis BCG antigens (lanes 1) with in-vitro-grown BCG, before (lanes 2) and after (lanes 3) heat shock are shown in Fig. 5(a-d). Only weak, non-specific immunoreactivity to THP-1 cell 

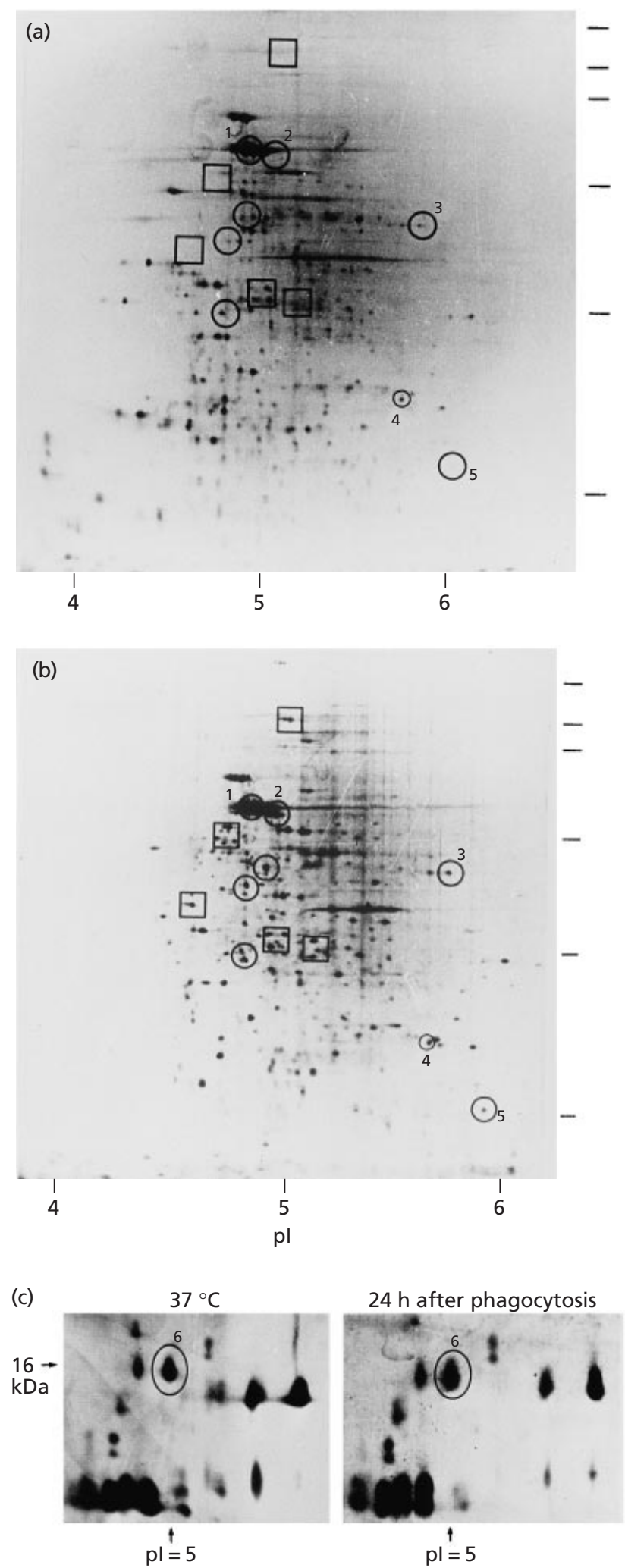

$24 \mathrm{~h}$ after phagocytosis

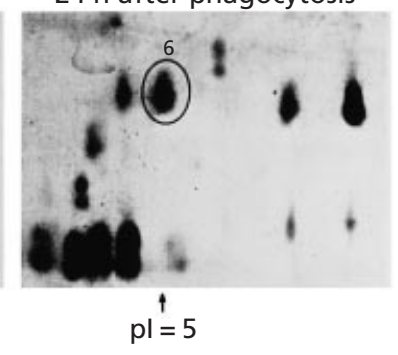

Fig. 4. Representative $2 \mathrm{D}$ gel electrophoresis analysis of silverstained total protein profiles of $M$. bovis BCG grown in vitro at $37{ }^{\circ} \mathrm{C}$ (a) and after $24 \mathrm{~h}$ phagocytosis within THP-1 cells (b). Proteins were separated in the first dimension by isoelectric focusing (IEF) within a $\mathrm{pH}$ range of 3-10 and separated in the second dimension by $10 \%$ SDS-PAGE. (c) A panel insert of low- lysates (Fig. 5c, lane 4) was seen, thus excluding the possibility that THP-1 cell proteins were contributing to the differential immunoreactivity between intracellular and in-vitro-grown BCG. No differences were observed for the in-vitro-grown BCG profiles with and without heat shock for any sera group (Fig. 5a-d, compare lanes 2 and 3) and weak cross-reactivity with the molecular mass markers was seen (lanes M). However, differences were observed between the intracellular BCG proteins and in-vitro-grown BCG for non-vaccinated (Fig. 5a), vaccinated (Fig. 5b) and M. tuberculosis-infected (Fig. $5 \mathrm{c}$, d) sera, further confirming intracellular differential gene expression. Although a degree of heterogeneity between individuals was observed, some antigens appeared to be TB-sera-specific.

Serum from a BCG-vaccinated control (Fig. 5b) generated a fairly similar immunoreactive profile to that of non-vaccinated sera (Fig. 5a), although an overall increase in the intensity of reactivity was observed. Of particular interest, was the appearance of a highly immunoreactive 'zone' which had not resolved itself as discrete individual bands (ranging in size from approximately $50 \mathrm{kDa}$ through to $30 \mathrm{kDa}$ ); this was present in the intracellular fraction (lane 1) but appeared only weakly in the two in vitro control lanes (lanes 2 and 3). The identification of this region was not experimentally established, but may possibly represent lipoarabinomanam (LAM), which has a similar mobility to that observed on SDS-PAGE gels (Hunter et al., 1986) and is also known to be highly immunoreactive. This zone was clearly a much more prominent feature of the Western blot profiles for M. tuberculosis-infected sera (Fig. 5c, d) and was much stronger in the intracellular BCG fractions compared to the in-vitro-grown controls.

Five different M. tuberculosis-infected sera were examined by Western blotting, two of which are represented here (Fig. 5c, d). M. tuberculosis-infected sera exhibited profiles broadly similar to that of BCG-vaccinated individuals, but showed much stronger reactivity. Several proteins expressed both in vitro and intracellularly were only recognized by $M$. tuberculosis-infected sera, including a $165 \mathrm{kDa}$ and a $58 \mathrm{kDa}$ protein, which showed strong reactivity against the intracellular BCG fraction. Furthermore, and of particular significance, was the fact that four intracellular BCG proteins, of $180,88,74$ and $28 \mathrm{kDa}$, were specifically recognized by M. tuberculosis-infected sera when compared to the in-vitro-grown BCG controls.

molecular-mass proteins from part of a $12.5 \%$ SDS-PAGE gel, showing up-regulation of the $\alpha$-crystallin antigen. Approximate pl range given on all figures was experimentally established using IEF standards. Squares indicate abundant proteins only expressed intracellularly. Circles indicate up-regulation in the levels of expression compared to growth in vitro. Pointers in (a) and (b) indicate the positions of molecular mass markers, which are as described in the legend to Fig. 1. All differences were assessed by eye. Protein spots excised for MS analysis are numbered and listed in Table 1. 
Table 1. Identification by MS of M. bovis BCG proteins differentially expressed inside THP-1 cells

\begin{tabular}{|c|c|c|c|c|c|c|c|c|}
\hline Spot* & Protein & Rv no. & $\begin{array}{l}\text { SWISS-PROT } \\
\text { accession no. }\end{array}$ & $\begin{array}{l}\text { Molecular } \\
\text { mass }(\mathrm{kDa}) \dagger\end{array}$ & $\mathrm{pI} \dagger$ & $\begin{array}{c}\text { Identification } \\
\text { technique }\end{array}$ & $\begin{array}{l}\text { No. of } \\
\text { peptides } \\
\text { matched }\end{array}$ & $\begin{array}{c}\text { Sequence } \\
\text { coverage } \\
(\%) \neq\end{array}$ \\
\hline 1 & GroEL-2 & Rv0440 & P06806 & $56 \cdot 6$ & $4 \cdot 85$ & MALDI & 19 & $35 \cdot 4$ \\
\hline 2 & GroEL-1 & Rv3417c & Q59573 & $55 \cdot 9$ & $4 \cdot 84$ & NanoES & 6 & $14 \cdot 3$ \\
\hline 3 & EF-Tu (Tuf) & Rv0685 & P31501 & $43 \cdot 6$ & $5 \cdot 28$ & MALDI & 5 & $20 \cdot 7$ \\
\hline 4 & $\begin{array}{l}\text { Hypothetical } 31.7 \mathrm{kDa} \\
\text { protein }\end{array}$ & Rv2623 & O06189 & $31 \cdot 7$ & $5 \cdot 61$ & NanoES & 3 & $10 \cdot 4$ \\
\hline 5 & InhA & Rv1484 & P46533 & $28 \cdot 6$ & $6 \cdot 04$ & NanoES & 1 & $3 \cdot 7$ \\
\hline 6 & $\begin{array}{l}16 \mathrm{kDa} \text { antigen } \\
(\alpha \text {-crystallin, } \mathrm{HspX})\end{array}$ & Rv2031 & P30223 & $16 \cdot 1$ & $4 \cdot 85$ & MALDI & 6 & $37 \cdot 1$ \\
\hline
\end{tabular}

*Spot number of protein resolved on 2D gel shown in Fig. 4.

†Predicted from SWISS-PROT database.

$\ddagger$ Percentage of gene represented within all peptides analysed.

(a)

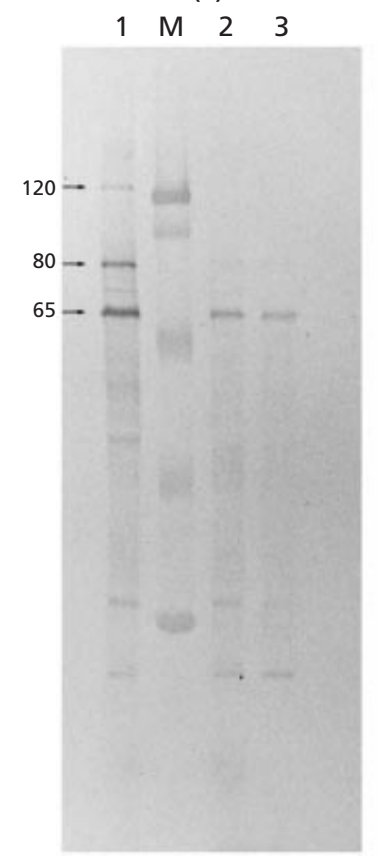

(b)

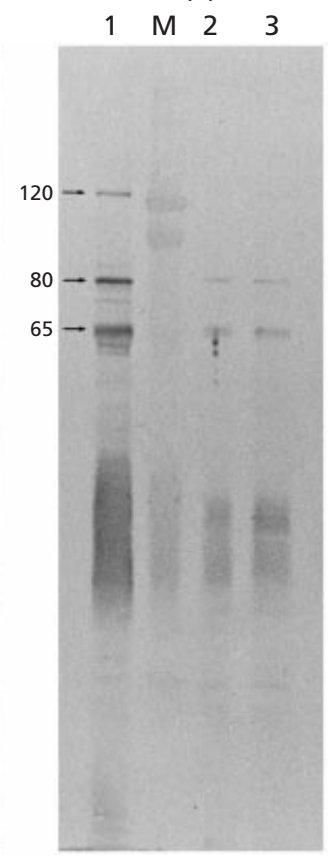

(c)

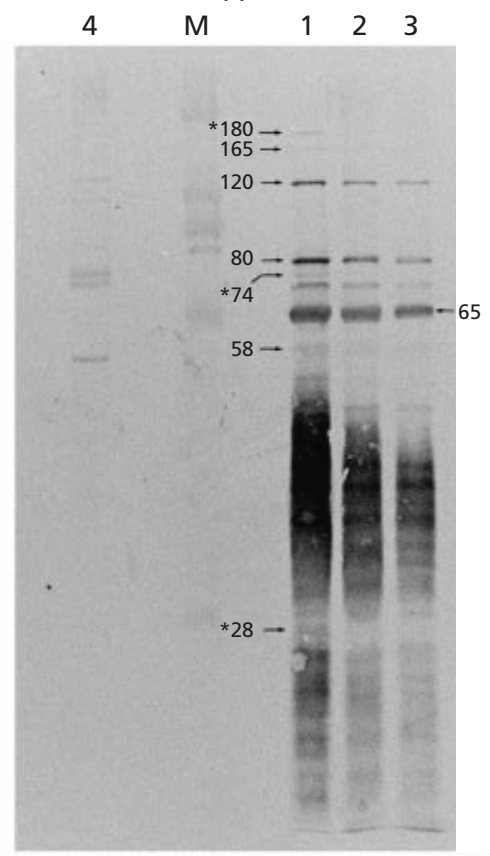

(d)

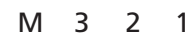

Fig. 5. Representative Western blot analysis of sera from three different patient populations to $M$. bovis BCG antigens. Total proteins of intracellular BCG recovered after $24 \mathrm{~h}$ from THP-1 cells (lane 1) and in-vitro-grown BCG before (lane 3) and after (lane 2) heat shock were run on a 10\% SDS-PAGE and incubated with a 1:100 dilution of (a) uninfected, nonvaccinated sera $(n=3)$, (b) BCG-vaccinated sera $(n=1)$, and (c, d) TB-infected sera $(n=5)$. Total THP-1 proteins (lane 4) were included as a control. Common antigens of 120,80 and $65 \mathrm{kDa}$ are indicated in all four panels for ease of comparison between each sera type. Asterisks highlight novel intracellular antigens only recognized by $M$. tuberculosisinfected sera. Lane M contains molecular mass markers as described in the legend to Fig. 1.

\section{DISCUSSION}

These results describe an experimental system in which the gene expression patterns of mycobacteria residing within macrophages can be monitored both at the de novo protein synthesis level by radiolabelling and at the total protein level by silver staining using $1 \mathrm{D}$ and $2 \mathrm{D}$ gel electrophoresis. Unique to this study is that mycobacterial proteins were prepared free from contaminating host cell proteins by a method that involved differential lysis of the macrophages and recovery of the intact intracellular bacilli. This enabled the mycobacterial proteins to be readily characterized immunologically by Western blot analysis and to be subsequently 
identified from 2D gels by proteomics using MALDI and nanoES MS. We have shown that $M$. bovis BCG, an attenuated strain of $M$. bovis, retains the ability to differentially express proteins while inside THP-1 macrophage-like cells even though it has been shown to be a regulatory and deletion mutant (Mahairas et al., 1996; Behr et al., 1999). These BCG proteins expressed inside macrophages are likely to play a role in intracellular survival and adaptation, which probably contributes to the immunoprotective effect of BCG. Our results with $1 \mathrm{D}$ gels also show that different proteins are expressed at different time intervals during the course of macrophage infection, reflecting the dynamic intracellular environment of the mycobacteria during a complex series of molecular interactions between the cell and the bacillus following phagocytosis. Intracellular mycobacterial protein profiles could thus be useful gene expression markers for endosome trafficking events that may be different for virulent $M$. tuberculosis compared to BCG, and which lead either to immunopathology and hence disease or different degrees of immunoprotection, respectively.

A wide variety of proteins were differentially expressed during BCG interaction with THP-1 cells, and it would also appear that the majority of intracellular modulation of protein expression occurred within the first 12-24 h following phagocytosis. Similarly, upon comparison of BCG in RPMI media alone and the extracellular BCG remaining after infection of macrophages (Fig. 1, lane 3 compared to lanes 8 and 9), we were able to demonstrate that direct contact with or close proximity to the macrophage brought about a series of phenotypic changes. Such a phenomenon has been described for the intracellular bacteria Salmonella and Shigella which, on contact with cells, induce class III secretory protein systems which result in the delivery to the cell of bacterial effector proteins that modify the macrophage or epithelial cell for subsequent invasion by the bacteria (for a recent review, see Bourdet-Sicard \& Tran Van Nhieu, 1999). Whether such systems operate in mycobacteria remains to be shown.

Identification of individual proteins as bands by 1D gels is of limited value, because several proteins of the same molecular mass will migrate similarly. There may well be unique proteins present in our intracellular fractions, but on a 1D gel these are often only visualized as an increase in band intensity (e.g. Fig. 1, lane 4; $50 \mathrm{kDa}$ ). This is obvious from our 2D gel profiles where many proteins were observed at the same molecular mass and which would resolve as single bands on 1D gels. Direct observation of $1 \mathrm{D}$ gels suggests the presence of unique intracellular bands (e.g. Fig. 1; 16, 28 and $110 \mathrm{kDa}$ ), the identity of which, however, can only be confirmed by 2D gel and MS analysis. Time course analysis of intracellular gene expression by radiolabelling and proteomics is clearly warranted to validate our $1 \mathrm{D}$ gel data, as presented in Fig. 1. In this way, the contribution of $d e$ novo synthesis versus protein stability can be addressed, which may be an important feature of the posttranscriptional control of gene expression in bacteria.
The results presented in this paper with regard to the upregulation of GroEL-1/GroEL-2, appear to confirm those obtained in two previous studies which have examined the response of $M$. tuberculosis to intracellular residence within murine (Alavi \& Affronti, 1994) and human (Lee \& Horwitz, 1995) macrophages. In both of these studies, it was revealed that Hsp65 was up-regulated within the mouse IC-21 cell line (Alavi \& Affronti, 1994), while the expression of both Hsp65 and Hsp70 was observed to have increased upon intracellular residence within the human THP-1 cell line (Lee \& Horwitz, 1995). We were able to confirm by MS that both GroEL-1 and GroEL-2 were up-regulated, at least after a $24 \mathrm{~h}$ phagocytosis period. This would clearly suggest that molecular chaperonins play an important role in the adaptation of mycobacteria during the course of infection. The M. tuberculosis $16 \mathrm{kDa} \alpha$-crystallin homolgue, encoded by the $h s p X$ gene, is a member of the small heat-shock protein family of chaperones. Its expression increases during the transition from exponential-phase growth to stationary phase and it becomes one of the most abundant proteins in stationary phase (Yuan et al., 1996; Hu et al., 1998). Similarly, it has also been shown to be induced on ribosomes under oxygendeficient conditions (Tabira et al., 1998). Indeed, recent evidence points to $\alpha$-crystallin's involvement in cell wall thickening under microaerophilic or anaerobic cultures of M. tuberculosis, and a stabilizing role for cell structures during long-term survival has been proposed (Cunningham \& Spreadbury, 1998). A gene replacement mutant for $h s p X$ in $M$. tuberculosis showed no differences for in vitro growth, but was significantly impaired for growth in bone-marrow-derived macrophages and THP-1 cells (Yuan et al., 1998a). Together with our data that demonstrates increased expression by $M$. bovis BCG inside THP- 1 cells, an emerging role is indicated for $h s p X$ both in the maintenance of long-term viability and in early stages of adaptation to intracellular environments.

InhA is an NADH-dependent long-chain enoyl-acyl carrier protein reductase (enoyl-ACP reductase) that is essential in $M$. tuberculosis for the biosynthesis of mycolic acid, a major component of mycobacterial cell walls. It is the primary target for the anti-tuberculous drug isoniazid (Banerjee et al., 1994). In vivo labelling of mycolic acids during growth of M. tuberculosis H37Rv within THP-1 cells has revealed a substantial increase in keto- and alpha-mycolate synthesis and strains lacking ketomycolate were severely growth-impaired (Yuan et al., 1998b). Our findings of increased expression of InhA by $M$. bovis BCG within THP-1 cells are entirely consistent with these studies and support a critical role for mycolate composition in proper cell wall function during growth of M. tuberculosis in vivo (Yuan et al., 1998b).

Examination of the other proteins with increased expression and identified by MS, is less instructive. The increase in EF-Tu (Tuf) expression may reflect either an overall increase in protein synthesis associated with growth in the intracellular environment or may indicate 
some regulatory function in translational control of gene expression. In this regard, a recent publication has demonstrated that EF-Tu is up-regulated when $M$. tuberculosis is exposed to high iron conditions in vitro (Wong et al., 1999). Alternatively, the 2D gel spot observed to be EF-Tu may represent a covalent modification event leading to alternative positioning on the gel and apparent identification by proteomics simply as EF-Tu. No information is available for the hypothetical $31.7 \mathrm{kDa}$ protein.

The limited immunological characterization with human sera by Western blotting of proteins from intracellular and in-vitro-grown BCG (Fig. 5) showed: (i) that a subset of proteins appear to be TB-sera specific, (ii) that antibody reactivity was stronger in infected sera, and (iii) that four proteins (of $180,88,74$ and $28 \mathrm{kDa}$ ) expressed by intracellular but not by in-vitro-grown BCG were uniquely recognized only by TB-infected sera. The fact that these proteins from intracellular bacteria were found to be highly immunoreactive highlights their potential use as immunoprotective antigens in the construction of recombinant vaccines or as markers for the differentiation between vaccination and disease. Detailed characterization of these antigens with larger numbers of sera combined with 2D gel analysis is clearly required.

Several parameters of the model system described here and used to study mycobacterial gene expression during macrophage interaction were critical both to its development and validity. Firstly, our experiments demonstrated that at least $10^{8}$ mycobacteria are required to visualize proteins both by radiolabelling and silver staining. The use, therefore, of the human THP-1 macrophage cell line, rather than human peripheralblood-monocyte-derived macrophages or alveolar macrophages, was necessary to provide sufficient cells (approx. $5 \times 10^{7}$ ) from which to recover in the order of $10^{8}$ intracellular mycobacteria. The yields of intracellular BCG were just sufficient for silver staining and protein profile comparisons using 2D gels. MS has become the method of choice for the identification of proteins from polyacrylamide gels, with both MALDI and tandem electrospray MS capable of sensitivity in the low nanomolar range (reviewed by Humphery-Smith et al., 1997). Here, we have successfully applied these techniques to the analysis of small amounts of intracellular BCG proteins recovered from our macrophage infection model. We have been able to identify six BCG proteins which were up-regulated, at least after a $24 \mathrm{~h}$ phagocytosis period. It is important to point out, however, that these six proteins were expressed at higher levels than many of the other differentially expressed silver-stained proteins observed, which failed to provide interpretable data from MS analysis. Further studies aimed at increasing spot detection sensitivity are currently in progress. Discrepancy between observed and predicted protein $\mathrm{pI}$ values is a common feature of proteomic analysis using $2 \mathrm{D}$ gels. This is considered to be due to, amongst other things, conformational differences, post-translational modification and other pro- cessing events of proteins affecting their migration. To our knowledge, MS identification of mycobacterial proteins from 2D gels has only been applied so far to invitro-grown cultures, in which abundant amounts of protein are available for analysis (Jungblut et al., 1999; Mollenkopf et al., 1999; Wong et al., 1999). Our study therefore represents a major advance in the analysis of mycobacterial protein expression during host-pathogen interactions, where the yield of intracellular mycobacteria using infection models is limiting.

Secondly, the choice of THP-1 cells was based on their close resemblance to human-derived macrophages as these cells have both $\mathrm{Fc}$ and $\mathrm{C} 3 \mathrm{~b}$ receptors and are devoid of surface and cytoplasmic immunoglobulins (Tsuchiya et al., 1980). As well as producing lysozymes and demonstrating increased $\mathrm{O}_{2}$ consumption upon phagocytosis (Tsuchiya et al., 1980, 1982), THP-1 cells also produce IL-8 and the monocyte-activating and chemoattractant proteins MCAF and MCP-1, respectively, in response to $M$. tuberculosis infection in vitro (Friedland et al., 1992, 1993).

Thirdly, our model system avoids the need to block macrophage protein synthesis with cycloheximide since after selective lysis, which is dependent on the intrinsic resistance of mycobacteria to lysis, only mycobacterial proteins are resolved by electrophoresis (as shown in Fig. 1). This procedure is in fact an extension of the common method used for assessing the viability of intracellular mycobacteria (Banerjee \& Patel, 1994), where SDS has been shown not to affect viability (Bermudez \& Champsi, 1993). It has been demonstrated in numerous studies that host cells parasitized by intracellular pathogens increase their own protein synthesis in order to protect themselves from their effector molecules as well as from the invading parasite itself (Kantengwa et al., 1991; Kaufmann, 1991; Kaufmann et al., 1991; Polla, 1988). Indeed, Schwann cells increase their level of Hsp60 and Hsp70 upon infection with Mycobacterium leprae (Kaufmann et al., 1991; Mistry et al., 1992). The addition of cycloheximide would prevent macrophage protein synthesis and hence may affect the molecular interactions or so-called 'crosstalk' between the host cell and pathogen. This could consequently have some impact on cytokine expression, antigen presentation and mycobacterial trafficking through the macrophage, and thus affect the expression of bacterial virulence determinants in response to cellular signals. In fact, two recent publications which have examined the intracellular synthesis of Salmonella typhimurium and Legionella pneumophila proteins highlight the importance and validity of specifically labelling bacterial proteins by a method which does not interfere with the metabolic activities of the host cell (Burns-Keliher et al., 1997; Kwaik, 1998). One disadvantage of SDS selective lysis and release of intracellular mycobacteria, however, is that bacterial secreted proteins or weakly associated extrinsic proteins may be lost from or disproportionately reduced in the analysis.

It is also important to note that the THP- 1 cell line may 
not induce the same mycobacterial gene expression patterns as might be observed in other macrophage cell lines or natural macrophages, such as alveolar macrophages or peripheral-blood-monocyte-derived macrophages. This has already been shown to be the case with S. typhimurium (Buchmeier \& Heffron, 1990; Abshire \& Neidhardt, 1993). Clearly the type of cell line used for the examination of Mycobacterium-macrophage interactions will also influence the bacterial protein profiles generated. Several reports have demonstrated that the use of different cell lines and culture conditions can significantly influence the intracellular survival of mycobacteria (Mehta et al., 1996; Barker et al., 1996). Comparative protein profiling is clearly necessary and will be facilitated by the emerging partial protein profile and proteome maps for mycobacteria (Urquhart et al., 1996, 1998; Jungblut et al., 1999; Mollenkopf et al., 1999) in combination with the methods described here.

In conclusion, therefore, the differential protein expression by $M$. bovis BCG following phagocytosis by THP-1 cells indicates that this mycobacterial species has a specific response to the intracellular macrophage environment, suggesting that the expression of preferred proteins is essential for survival. The mechanisms by which mycobacteria survive the potentially hostile environment of the macrophage are fundamental to our understanding of their virulence and pathogenicity. The results presented here go some way to achieving this aim, but moreover represent the development of valid models with which to further characterize differentially expressed genes. The use of such models may help elucidate the early molecular events involved in $\mathrm{Myco-}$ bacterium-macrophage interactions. A comparison of intracellular protein profiles of virulent M. tuberculosis with those of attenuated strains, such as BCG, by using the more discriminating methods of $2 \mathrm{D}$ gels, could differentiate genes responsible for virulence and pathogenicity. Such studies would be in line with the emerging hypothesis that bacterial virulence depends on the correct temporal and spatial expression of overlapping sets of genes in response to environmental cues.

\section{ACKNOWLEDGEMENTS}

We are grateful to Dr William R. Jacobs, Jr, Albert Einstein College of Medicine, New York, for his help in enabling us to undertake some of the 2D gel work presented here. This work was supported by the Medical Research Council (grant G9328099PB) and EU Biomed 2 (grant BMH4-CT97-2671). We acknowledge GlaxoWellcome Action TB programme for current financial support for I. M.M.

\section{REFERENCES}

Abshire, K. Z. \& Neidhardt, F. C. (1993). Analysis of proteins synthesised by Salmonella typhimurium during growth within a host macrophage. J Bacteriol 175, 3734-3743.

Alavi, M. R. \& Affronti, L. F. (1994). Induction of mycobacterial proteins during phagocytosis and heat shock: a time interval analysis. J Leukoc Biol 55, 633-641.

Arruda, S., Bomfim, G., Knights, R., Huima-Byron, T. \& Riley, L. W.
(1993). Cloning of an M. tuberculosis DNA fragment associated with entry and survival inside cells. Science 261, 1454-1457.

Banerjee, D. K. \& Patel, B. K. R. (1994). Evaluation of the activity of a number of antimicrobial agents against mycobacteria within mouse macrophages by a radiometric method. I Antimicrob Chemother 31, 289-302.

Banerjee, A., Dubnau, E., Quemard, A., Balasubramanian, V., Um, K. S., Wilson, T., Collins, D., de Lisle, G. \& Jacobs, W. R., Jr (1994). inh $A$, a gene encoding a target for isoniazid and ethionamide in Mycobacterium tuberculosis. Science 263, 227-230.

Barker, K., Fan, H., Carroll, C., Kaplan, G., Barker, J., Hellmann, W. \& Cohn, Z. A. (1996). Nonadherent cultures of human monocytes kill Mycobacterium smegmatis, but adherent cultures do not. Infect Immun 64, 428-433.

Behr, M. A., Wilson, M. A., Gill, W. P., Salamon, H., Schoolnik, G. K., Rane, S. \& Small, P. M. (1999). Comparative genomics of BCG vaccines by whole genome DNA microarray. Science 284, 1520-1523.

Bermudez, L. E. \& Champsi, J. (1993). Infection with Mycobacterium avium induces production of interleukin-10, and administration of anti-IL-10 antibody is associated with enhanced resistance to infection in mice. Infect Immun 61, 3093-3097.

Bourdet-Sicard, R. \& Tran Van Nhieu, G. (1999). Actin reorganisation by SipA and Salmonella invasion of epithelial cells. Trends Microbiol 7, 309-310.

Bradford, M. M. (1976). A rapid and sensitive method for the quantitation of microgram quantities of protein utilizing the principle of protein-dye binding. Anal Biochem 72, 248-254.

Buchmeier, N. A. \& Heffron, F. (1990). Induction of Salmonella stress proteins upon infection of macrophages. Science 248, 730-732.

Burns-Keliher, L. L., Portteus, A. \& Curtiss, R., 3rd (1997). Specific detection of Salmonella typhimurium proteins synthesized intracellularly. J Bacteriol 179, 3604-3612.

Cole, S. T., Brosch, R., Parkhill, J. \& 39 other authors (1998). Deciphering the biology of Mycobacterium tuberculosis from the complete genome sequence. Nature 393, 537-544.

Collins, D. M., Kawakami, R. P., de Lisle, G. W., Pascopella, L., Bloom, B. R. \& Jacobs, W. R., Jr (1995). Mutation of the principal $\sigma$ factor causes loss of virulence in a strain of the Mycobacterium tuberculosis complex. Proc Natl Acad Sci U S A 92, 8036-8040.

Cunningham, A. F. \& Spreadbury, C. L. (1998). Mycobacterial stationary phase induced by low oxygen tension: cell wall thickening and localization of the 16-kilodalton alpha-crystallin homolog. J Bacteriol 180, 801-808.

Friedland, J. S., Remick, D. G., Shattock, R. \& Griffin, G. E. (1992). Secretion of interleukin-8 following phagocytosis of Mycobacterium tuberculosis by human monocyte cell lines. Eur $J$ Immunol 22, 1373-1378.

Friedland, J. S., Shattock, R. \& Griffin, G. E. (1993). Phagocytosis of Mycobacterium tuberculosis or particulate stimuli by human monocytic cells induces equivalent monocyte chemoattractant protein-1 gene expression. Cytokine 5, 150-156.

Gupta, S. \& Tyagi, A. K. (1993). Sequence of a newly identified Mycobacterium tuberculosis gene encoding a protein with sequence homology to virulence regulating proteins. Gene 126, 157-158.

Hu, Y. M., Butcher, P. D., Sole, K., Mitchison, D. A. \& Coates, A. R. (1998). Protein synthesis is shutdown in dormant Mycobacterium tuberculosis and is reversed by oxygen or heat shock. FEMS Microbiol Lett 158, 139-145.

Humphery-Smith, I., Cordwell, S. J. \& Blackstock, W. P. (1997). 
Proteome research : complementarity and limitations with respect to the RNA and DNA worlds. Electrophoresis 18, 1217-1242.

Hunter, S. W., Gaylord, H. \& Brennan, P. J. (1986). Structure and antigenicity of the phosphorylated lipopolysaccharide antigens from the leprosy and tubercle bacilli. J Biol Chem 261, 1234512351.

Jensen, O. N., Podtelejnikov, A. \& Mann, M. (1996). Delayed extraction improves specificity in database searches by matrixassisted laser desorption/ionization peptide maps. Rapid Commun Mass Spectrom 10, 1371-1378.

Jensen, O. N., Wilm, M., Shevchenko, A. \& Mann, M. (1999). Sample preparation methods for mass spectrometric peptide mapping directly from 2-DE gels. Methods Mol Biol 112, 513-530.

Jungblut, P. R., Schaible, U. E., Mollenkopf, H. J. \& 7 other authors (1999). Comparative proteome analysis of Mycobacterium tuberculosis and Mycobacterium bovis BCG strains: towards functional genomics of microbial pathogens. Mol Microbiol 33, 1103-1117.

Kantengwa, S., Donati, Y. R. A., Clerget, M. \& 7 other authors (1991). Heat shock proteins: an autoprotective mechanism for inflammatory cells? Semin Immunol 3, 49-56.

Kaufmann, S. H. E. (1991). Heat shock proteins and pathogenesis of bacterial infections. Springer Semin Immunopathol 13, 25-36.

Kaufmann, S. H. E., Schoel, B., van Embden, J. D. A., Koga, T., Wand-Wurttenberger, A., Munk, M. E. \& Steinhoff, U. (1991). Heat-shock protein 60: implications for pathogenesis of and protection against bacterial infections. Immunol Rev 121, 67-90.

Kinger, A. K. \& Tyagi, J. S. (1993). Identification and cloning of genes differentially expressed in the virulent strain of Mycobacterium tuberculosis. Gene 131, 113-117.

Kwaik, Y. A. (1998). Induced expression of the Legionella pneumophila gene encoding a 20-kilodalton protein during intracellular infection. Infect Immun 66, 203-212.

Laemmli, U. K. (1970). Cleavage of structural proteins during the assembly of the head of bacteriophage T4. Nature 227, 680-685.

Lee, B.-Y. \& Horwitz, M. A. (1995). Identification of macrophage and stress-induced proteins of Mycobacterium tuberculosis. J Clin Invest 96, 245-249.

Mahairas, G. G., Sabo, P. J., Hickey, M. J., Singh, D. C. \& Stover, C. K. (1996). Molecular analysis of genetic differences between Mycobacterium bovis BCG and virulent M. bovis. J Bacteriol 178, 1274-1282.

Mann, M. \& Wilm, M. (1994). Error-tolerant identification of peptides in sequence databases by peptide sequence tags. Anal Chem 66, 4390-4399.

Mehta, P. K., King, C. H., White, E. H., Murtagh, J. J., Jr \& Quinn, F. D. (1996). Comparison of in vitro models for the study of Mycobacterium tuberculosis invasion and intracellular replication. Infect Immun 64, 2673-2679.

Mekalanos, J. J. (1992). Environmental signals controlling gene expression of virulence determinants of bacteria. J Bacteriol 174, $1-7$.

Mistry, Y., Young, D. B. \& Mukherjee, R. (1992). hsp70 synthesis in Schwann cells in response to heat shock and infection with Mycobacterium leprae. Infect Immun 60, 3105-3110.

Mollenkopf, H.-J., Jungblut, P. R., Raupach, B., Mattow, J., Lamer, S., Zimny-Arndt, U., Schaible, U. E. \& Kaufmann, S. H. E. (1999). A dynamic bacterial two-dimensional polyacrylamide gel electrophoresis database: the mycobacterial proteome via Internet. Electrophoresis 20, 2172-2180.

Morrissey, J. H. (1981). Silver stain for proteins in polyacrylamide gels: a modified procedure with enhanced uniform sensitivity. Anal Biochem 117, 307-310.

O'Farrell, P. H. (1975). High-resolution two-dimensional electrophoresis of proteins. J Biol Chem 250, 4007-4021.

Pascopella, L., Collins, F. M., Martin, J. M., Lee, M. H., Hatfull, G. F., Stover, C. H., Bloom, B. R. \& Jacobs, W. R., Jr (1994). Use of in vivo complementation in Mycobacterium tuberculosis to identify a genomic fragment associated with virulence. Infect Immun 62, 1313-1319.

Patel, B. K. R., Banerjee, D. K. \& Butcher, P. D. (1991). Characterisation of the heat shock response in Mycobacterium bovis BCG. J Bacteriol 173, 99-111.

Plum, G. \& Clark-Curtiss, J. E. (1994). Induction of Mycobacterium avium gene expression following phagocytosis by human macrophages. Infect Immun 62, 476-483.

Plum, G., Brenden, M., Clark-Curtiss, J. E. \& Pulverer, G. (1997). Cloning, sequencing and expression of the mig gene of $\mathrm{Myco-}$ bacterium avium, which codes for a secreted macrophage-induced protein. Infect Immun 65, 4548-4557.

Polla, B. S. (1988). A role for heat shock proteins in inflammation? Immunol Today 9, 134-137.

Shevchenko, A., Wilm, M., Vorm, O. \& Mann, M. (1996). Mass spectrometric sequencing of proteins from silver-stained polyacrylamide gels. Anal Chem 68, 850-858.

Sturgill-Koszycki, S., Haddix, P. L. \& Russell, D. G. (1997). The interaction between Mycobacterium and the macrophage analyzed by two-dimensional polyacrylamide gel electrophoresis. Electrophoresis 18, 2558-2565.

Tabira, Y., Ohara, N., Kitaura, H., Matsumoto, S., Naito, M. \& Yamada, T. (1998). The $16-\mathrm{kDa}$ alpha-crystallin-like protein of Mycobacterium bovis BCG is produced under conditions of oxygen deficiency and is associated with ribosomes. Res Microbiol 149, 255-264.

Tsuchiya, S., Yambi, M., Yamaguchi, Y., Kobayashi, Y., Konno, T. \& Tada, K. (1980). Establishment and characterisation of a human acute monocytic leukaemia cell line (THP-1). Int J Cancer 26, 171-176.

Tsuchiya, S., Kobayashi, Y., Goto, Y., Okumura, H., Nakae, S., Konno, T. \& Tada, K. (1982). Induction of maturation in cultured human monocytic leukemia cells by a phorbol diester. Cancer Res 42, 1530-1536.

Urquhart, B. L., Atsalos, T. E., Roach, D., Basseal, D. J., Bjellqvist, B., Britton, W. L. \& Humphery-Smith, I. (1996). 'Proteomic contigs' of Mycobacterium tuberculosis and Mycobacterium bovis (BCG) using novel immobilised $\mathrm{pH}$ gradients. Electrophoresis 18, 1384-1392.

Urquhart, B. L., Cordwell, S. J. \& Humphery-Smith, I. (1998). Comparison of predicted and observed properties of proteins encoded in the genome of Mycobacterium tuberculosis H37Rv. Biochem Biophys Res Commun 253, 70-79.

Via, L. E., Curcic, R., Mudd, M. H., Dhandayuthapani, S., Ulmer, R. J. \& Deretic, V. (1996). Elements of signal transduction in Mycobacterium tuberculosis: in vitro phosphorylation and in vivo expression of the response regulator MtrA. J Bacteriol 178, 3314-3321.

Wilm, M. \& Mann, M. (1994). Electrospray and taylor-cone theory, Dole's beam of macromolecules at last? Int J Mass Spectrom Ion Proc 136, 167-180.

Wilm, M. \& Mann, M. (1996). Analytical properties of the nanoelectrospray ion source. Anal Chem 68, 1-8.

Wilm, M., Shevchenko, A., Houthaeve, T., Breit, S., Schweigerer, L., Fotsis, T. \& Mann, M. (1996). Femtomole sequencing of 
proteins from polyacrylamide gels by nano-electrospray mass spectrometry. Nature 379, 466-469.

Wilson, T. M., de Lisle, G. W. \& Collins, D. M. (1995). Effects of inh $A$ and $k a t G$ on isoniazid resistance and virulence of $\mathrm{Myco-}$ bacterium tuberculosis. Mol Microbiol 15, 1009-1015.

Wong, D. K., Lee, B.-Y., Horwitz, M. A. \& Gibson, B. W. (1999). Identification of fur, aconitase, and other proteins expressed by Mycobacterium tuberculosis under conditions of low and high concentrations of iron by combined two-dimensional gel electrophoresis and mass spectrometry. Infect Immun 67, 327-336.

Wren, B. W., Colby, S. M., Cubberley, R. R. \& Pallen, M. J. (1992). Degenerate PCR primers for the amplification of fragments from genes encoding response regulators from a range of pathogenic bacteria. FEMS Microbiol Lett 99, 287-292.

Yuan, Y., Crane, D. D. \& Barry, C. E., III. (1996). Stationary phase- associated protein expression in Mycobacterium tuberculosis: function of the mycobacterial $\alpha$-crystallin homolog. J Bacteriol 178, 4484-4492.

Yuan, Y., Crane, D. D., Simpson, R. M., Zhu, Y. Q., Hickey, M. J., Sherman, D. R. \& Barry, C. E., 3rd (1998a). The 16-kDa alpha crystallin (Acr) protein of Mycobacterium tuberculosis is required for growth in macrophages. Proc Natl Acad Sci USA 95, 9578-9583.

Yuan, Y., Zhu, Y., Crane, D. D. \& Barry, C. E., 3rd (1998b). The effect of oxygenated mycolic acid composition on cell wall function and macrophage growth in Mycobacterium tuberculosis. Mol Microbiol 29, 1449-1458.

Received 19 April 2000; revised 22 August 2000; accepted 13 October 2000 